\title{
THE PROPOSAL OF A PROGRAM FOR CONTROL, SUPPRESSION AND ERADICATION OF BOVINE VIRAL DIARRHEA VIRUS INFECTION IN CATTLE HERDS IN THE REPUBLIC OF SERBIA
}

\author{
Tamaš Petrović ${ }^{1^{*}}$, Sava Lazić ${ }^{1}$, Dejan Bugarski ${ }^{1}$, Diana Lupulović ${ }^{1}$, \\ Vladimir Polaček ${ }^{1}$, Dejan Vidanović ${ }^{2}$, Budimir Plavšić ${ }^{3}$ \\ ${ }^{1}$ Scientific Veterinary Institute „Novi Sad“, Novi Sad, Serbia \\ ${ }^{2}$ Specialized Veterinary Institute "Kraljevo", Kraljevo, Serbia \\ ${ }^{3}$ Veterinary Directorate, Ministry of Agriculture and \\ Environmental Protection, Belgrade, Serbia
}

Abstract

Bovine Viral Diarrhoea (BVD) is a viral infection of cattle caused by Bovine Viral Diarrhoea Virus (BVDV). The most important source of infection is persistently infected and sick cattle, but also other susceptible species. BVDV infection, except for cattle, occurs in sheep, pigs, goats and wild ruminants. These animals can be reservoirs of the virus, and thus the source of infection. The greatest economic losses caused by BVDV infection in cattle farming are the direct consequences of transplacental infection, as a result of foetal deaths, congenital malformations, neonatal and postnatal mortality, including mucosal diseases and slow growth and poor performance results of the surviving animals, as well as acute infections of respiratory and alimentary infections. Economic losses due to BVDV infection can be seen in a cattle herd even several years after the infection. Moreover, BVDV infection is considered as the third most important disease to cattle farming industry, immediately after rinderpest and the foot-and-mouth disease. The primary task of BVDV infection control is to prevent prenatal infection. This procedure includes the determination and elimination of persistently infected (PI) animals from the herd. After the removal of these animals, great attention must be paid to introducing new animals into the herd and preventing the occurrence of transplacental infection. On the basis of existing data and real suppositions about the distribution of BVDV infection in the territory of Serbia, the great economic damages it causes, as

${ }^{1 *}$ Corresponding author: tomy@niv.ns.ac.sr 
well as the general tendency to resolve problems in European states, and for the competitiveness of our farmers and food industries in the production of milk, meat or breeding material after joining the EU market, it is necessary to draft legal regulations in the control of this bovine viral disease in Serbia. The mentioned control could be based on the voluntary BVDV eradication program on herd's level in the beginning and on establishing herds with BVDV free status. Certification of BVDV free status of herd will be done by Veterinary Directorate, and the register of herds with BVDV free status could be "on line" available and maintained by the Veterinary Directorate. The essence of this proposal, a volunteer program of establishing herds with BVDV free status, is based on several steps or phases, which includes frequent diagnostic testing, removal of PI animals from the herd and the introduction of strict biosecurity measures.

Key words: BVD, control program proposal, Serbia

\title{
PREDLOG PROGRAMA KONTROLE, SUZBIJANJA I ISKORENJIVANJA INFEKCIJE IZAZVANE VIRUSOM GOVEĐE VIRUSNE DIJAREJE U ZAPATIMA GOVEDA U REPUBLICI SRBIJI
}

\author{
Tamaš Petrović ${ }^{* 1}$, Sava Lazić ${ }^{1}$, Dejan Bugarski ${ }^{1}$, Diana Lupulović ${ }^{1}$, \\ Vladimir Polaček ${ }^{1}$, Dejan Vidanović ${ }^{2}$, Budimir Plavšićc ${ }^{3}$ \\ ${ }^{1}$ Naučni institut za veterinarstvo „Novi Sad“, Novi Sad, Srbija \\ ${ }^{2}$ Veterinarski specijalistički institute Kraljevo”, Kraljevo, Srbija \\ ${ }^{3}$ Uprava za veterinu, Ministarstvo poljoprivrede i \\ zaštite životne sredine, Beograd, Srbija
}

\section{Kratak sadržaj}

Goveđa virusna dijareja (Bovine Viral Diarhea - BVD) je virusna infekcija goveda čiji je uzročnik virus goveđe virusne dijareje (Bovine Viral Diarhea Virus - BVDV). Najznačajniji izvor infekcije su perzistentno inficirana i bolesna goveda, a mogu biti i druge prijemčive vrste. Infekcija BVD virusom, osim kod goveda, javlja se kod ovaca, svinja, koza i divljih preživara. Ove životinje mogu biti i rezervoari virusa, a samim tim i izvor infekcije.

Najveće štete koje BVDV infekcija nanosi govedarstvu su direktne posledice transplacentarne infekcije, kao rezultat fetalnih uginuća, kongeni- 
talnih malformacija, neonatalnog i postnatalnog mortaliteta uključujući i bolest sluznica, slab rast i performanse preživelih životinja, kao i infekcije respiratornog i digestivnog trakta. Ekonomski gubici prouzrokovani BVDV infekcijom mogu se ispoljavati u zapatu goveda i nekoliko godina nakon infekcije, naime BVDV infekcija se smatra trećom bolesti po ekonomskom značaju u govedarstvu odmah iza kuge goveda i slinavke i šapa. Primarni zadatak kontrole BVDV infekcije je prevencija prenatalne infekcije. Ovaj postupak obuhvata i ustanovljavanje i otklanjanje perzistentno inficiranih (PI) jedinki iz zapata. Nakon otklanjanja PI životinja veliku pažnju treba posvetiti unošenju novih grla u zapat i sprečavanju pojave transplacentarne infekcije. Bovina virusna dijareja je značajno raširena u celom svetu. U razvijenim zemljama, procenat serološki pozitivnih životinja se kreće između 60-90\%. Ispitivanja raširenosti ove infekcije na području Srbije koja se sprovedena u poslednjih 15 godina ukazuju na njenu značajnu raširenost na području cele države i to kako u malim tako i u velikim zapatima goveda. $\mathrm{Na}$ osnovu ustanovljenih podataka i realnih pretpostavki o raširenosti BVDV infekcije na području Republike Srbije, velikih ekonomskih šteta do kojih ona dovodi, kao i na tendenciju rešavanja problema u evropskim državama i konkurentnosti stočara i prehrambene industrije iz Srbije u proizvodnji mleka, mesa ali i priplodnog materijala nakon pridruživanja tržištu EU, postoji potreba pokretanja regulative u kontroli ove virusne bolesti goveda u Republici Srbiji. Pomenuta kontrola bi se u početku mogla bazirati na dobrovoljnom programu eradikacije BVDV infekcije na nivoima zapata $i$ uspostavljanju zapata slobodnih od BVDV infekcije. Sertifikaciju zapata bi vršila Uprava za veterinu i vodila „on line“ dostupan registar takvih zapata sa svim podacima o zapatu i datumom važenja sertifikacije zapata. Suština ovog predloga volonterskog programa uspostavljanja zapata slobodnih od BVDV infekcije se zasniva na nekoliko koraka odnosno faza, koje obuhvataju učestala dijagnostička ispitivanja, uklanjanje PI jedinki iz zapata i uvođenje strogih biosigurnosnih mera.

Ključne reči: BVD, predlog programa kontrole, Srbija

\section{INTRODUCTION}

Bovine viral diarrhoea (BVD) is virus infection of cattle, which still remains a mystery for both cattle owners and clinician veterinarians and scientists even if it was first described decades ago by Olafson et al., in 1946. The causal agent is one of the smallest RNA viruses (Bovine Viral Diarrhoea Virus - BVDV) from the genus Pestivirus, family Flaviviridae. The most common 
source of infection are persistently infected and sick cattle, but also some other susceptible species such as sheep, swine, goat and a range of wild ruminants. These animal species could be also potential virus reservoirs in nature (Nettleton and Entrican, 1995).

The pathogenesis of BVDV in cattle is highly unique and manifests distinct features that are not observed in other infections of viral aetiology (Houe, 1999). Intrauterine infection of the foetus before 125 gestation day, because of the immaturity of foetal immune system, results in recognizing viral antigens as the own antigens, which in turn induces immune tolerance and persistent infection after they are born (Bronwlie et al., 1984; Bronwlie, 1991). Such persistently infected (PI) animals are usually born as clinically healthy, yet harbouring the virus that continues to replicate in their bodies and shedding it into the environment for life. In PI animals (mostly aged 6-24 months) mutation of the existing persistent noncytopathic (ncp) biotype of the virus to the cytopathic (cp) biotype occurs and consequently produces clinical form of mucosal disease (MD) with rapid fatal outcome. In view of that, the consequences of foetal infection including persistently infected (PI) animals and subsequent development of fatal mucosal disease are unique feature of BVDV infection (Bronwlie, 1991; Houe, 1999). Existence of noncytopathic and cytopathic viral strains and their complex relation toward susceptible animals, especially pregnant cows and their foetuses, as well as potential transmission to other susceptible species such as domestic and feral ruminants and pigs strongly emphasize the importance of better understanding of this viral infection of cattle.

BVD infection of cattle is characterized by a wide spectrum of clinical manifestations including transient fever, viral diarrhoea of cattle, respiratory disturbance, lower conception rate in breeding females, abortions, foetal mummification, congenital malformations, immune tolerance and persistent infection progressing to MD. Moreover, subclinical infection associated with leucopoenia and immunosuppression can occur (Baker, 1987).

BVD virus infection, both acute and subacute, is commonly associated with rather silent clinical manifestation or has a subclinical course. Thus, the infection often remains unnoticed in cattle herds or is neglected (Roeder and Harkness, 1986; Paton et al., 1999). The situation changes when the infection occurs in pregnant animals causing transplacental infection of the foetus. Substantial health and economic losses are due to frequent failed insemination, stillborn calves with congenital malformations, absence of conception, prolonged service periods, early embryonic mortality, abortions or delivery of PI offspring (Baker, 1987). Such persistently infected progeny are apparently clinically healthy yet remain viraemic for life and shed huge amounts of the 
virus into the environment via their secreta and excreta. Consequently, those animals are the most important reservoirs of the virus in the herd throughout their life (Baker, 1987; Bronwlie, 1991). The outcome of persistent infection is always fatal and due to clinical form of mucosal disease. In addition to the aforementioned direct losses, indirect damage associated with BVDV infection is far too broader and immeasurable for both individual herds and entire cattle production in the country.

The greatest damage for cattle industry associated with BVD directly implicate transplacental infections and consequent foetal mortality, congenital malformations, neonatal and postnatal mortality as well as mucosal disease, poor growth and performance of survivors (Roeder and Harkness, 1986). Considerable economic losses caused by BVDV infection can endanger the herd even for years after infection. For example, economic damage of BVDV infection on 14 cattle herds in The Netherlands was calculated to some 24-161 US Dollars per cow with an average loss of 77 USD (Houe, 1995). In Great Britain, total annual economic loss from BVDV infection is estimated to some 120 million British Pounds (Bitsch and Ronsholt, 1995). Calculated losses associated with BVDV in Denmark are some 17 million USD per year, whereas economic damage attributed only to mucosal disease in eight Danish cattle herds with about 115 animals ranged between 2,380 and 2,980 USD per farm (Houe, 1995).

These data clearly indicate the importance of BVD in cattle production. From economical point of view, BVDV infection is considered the third most important disease in cattle husbandry, immediately after Rinderpest and Footand-Mouth Disease. These are only some aspects of health problems and economic losses associated with BVDV infection. The abovementioned examples clearly suggest the rationale for a research study on occurrence, suppression and eradication of BVDV infection as well as resulting positive production effects. Such positive results also include the trade of breeding material free from BVDV infection and consequent improvement of the quality of cattle production in Europe and worldwide (Petrović et al., 2003/a).

In the Republic of Serbia, the first cases of BVD infection were identified on the basis on clinical picture and serological examination in 1966 and 1968, respectively (Cvetnić, 1983). Initial research on the prevalence of infection in Serbia date back to 1973, when testing for the presence of BVDV-specific antibodies was performed on 224 blood sera of cattle from six farms (four from the region of Banat and two from the regions of Belgrade and Valjevo). The results revealed 166 (74\%) seropositive animals (specific antibodies were detected in blood of animals that were in contact with the virus, i.e., infected). 
The percentage of seropositive cattle at individual farms ranged between $38.8 \%$ and 91\% (Belić et al., 1973).

By the beginning of 1990s, the examination of cattle from two farms in the area of Valjevo was performed. Of the 86 examined calves from a beef herd 48 (55.81\%) were seropositive, whereas the rate of seropositive animals from a dairy farm with total 178 cows ranged between $30.55 \%$ and $52.24 \%$ depending on the age (Kurčubić, 1993).

A range of serological surveys conducted during last 15 years revealed infection rates in the range of $0-100 \%$, depending on the farming system, herd size and territory. The percentage of seropositive animals is higher in northern and central parts of Serbia compared to the southern regions. The majority of big cattle herds (formerly public-owned farms) are characterized by high BVDV seroprevalence rate (the prevalence of seropositive animals ranges from $60 \%$ to even $100 \%)$. However, some of those herds are absolutely free from infection (Petrović et al., 2001; Petrović, 2002; Molnar et al., 2003; Petrović et al., 2003/a; Milošević et al., 2004; Petrović et al., 2004/a; Petrović, 2006).

The percentage of seropositive animals among cattle population in small herds or backyards (few cows in a household) is significantly lower, ranging from settlements that are completely seronegative to some villages with low percentage (up to 20\%) of seropositive animals. Still, there are some exceptions - in some areas the seropositivity of even $60 \%$ has been observed among cattle population in particular villages or regions (Petrović T. et al., 2002; Petrović M. et al, 2002; Molnar et al., 2003; Petrović et al., 2004/a; Petrović et al., 2005; Petrović, 2006). This is mostly attributed to frequent purchasing of breeding material from big and infected herds or collective grazing of cattle on common land. Considering the wide spread of BVDV infection in our epizootical regions understanding of its economic implications as well as control options is of crucial importance (Petrović et al., 2003/b).

The first extensive researches of isolation and genotyping of BVDV isolates in Serbia were performed in the period 1999-2004 revealing the presence of BVDV genotype 1 and subtypes 1f, $1 \mathrm{~b}$ and $1 \mathrm{~g}$ (Petrović et al., 2004/b; Petrović, 2006). At that time, BVDV2 genotype has not been identified in Serbia; however, it was introduced in 2008 through cattle trade (unpublished information).

According to the obtained data and convincing anticipation about prevalence of BVD infection in our country, substantial economic losses as well as the current problem-solving trends in EU countries and having in mind the competitiveness of our cattle owners in meat and dairy industry and in the production of breeding material after accession to EU market, the need for relevant legislation pertaining to management and control of this viral disease in 
Republic of Serbia cannot be emphasized enough. It is proposed that the control of infection should be initially based on a BVDV voluntary eradication program at herd level and establishment of BVDV-free herds. Certification of free herds would be administered by Veterinary Directorate, which would provide an online available database of BVDV-free herds containing relevant data on the herd and validity date of the certificate.

This article gives an overview of procedures for control and eradication of BVDV infection in the world. Also, a draft of the Program for the control, suppression and eradication of BVDV infection in cattle herds in the Republic of Serbia is presented, that is, preparatory procedures and methods for laboratory and epizootiological testing and monitoring aimed at elimination of PI animals as major infection source as well as obtaining and maintaining of BVDV-free status of the herd.

\section{CURRENT STATUS AND PERSPECTIVES OF BVD IN SERBIA AND WORLDWIDE}

BVD infection is widespread among cattle population worldwide. When speaking from an epizootiological point of view, the presence of infection is evident in almost all countries. The rate of infected animals, that is, that were in contact with the virus ranges between 60 and 90\% in countries with developed cattle industry. In the territory of former Yugoslavia, the infection has been first described by Đuričković et al., in 1966 on the basis of clinical picture and pathomorphological finding. Serological confirmation was realized by Cvetnić et al., in 1968 (Cvetnić S., 1983). The researches on the incidence of the infection in the territory of Serbia performed during past 20 years strongly indicate its significant prevalence throughout the country.

The strategy for control and eradication of BVDV infection has initially been launched in Scandinavian countries. The program was based on identification and elimination of PI animals from the herd without vaccination. Norway was the first country that understood the actual problem of BVDV infection and initiated the eradication program in 1993. Bulk milk samples originating from 26,430 dairy herds were examined using indirect ELISA. Other Scandinavian countries followed the procedure. Essentially, the program relies on the following steps: 1) identification of BVDV free herds, 2) prevention of the infection in these herds and 3) reduction of the number of infected herds (Waage et al., 1996). Reduction of the number of infected herds was accomplished through identification and removal of PI animals from the herd as well as prevention of acute infection outbreak (Oirshot et al., 1999; 
Bitsch and Ronsholt, 1995; Waage et al., 1996). If the repeated laboratory test has confirmed the presence of antibodies in the herd, bulk milk samples from 3-5 first-calf heifers were tested. In case of positive finding, further testing was performed using blood sera of five young animals aged 8-12 months. Herds suspected to have one or more PI animals underwent rigorous ban on trade with livestock or grazing cattle on common land until repeated testing confirms their BVDV-free status. Declaring of a herd as BVDV-free is based on two subsequent repeated serological demonstration of the absence of antibodies in bulk milk sample from the milk tank on the farm, bulk milk sample from first-calf heifers and in bulk sample of blood serum from young animals examined at least four months later (Waage et al., 1996).

National voluntary program for control and eradication of BVDV without vaccination started in Sweden after 10-year experience in BVDV control at local and regional levels. Eradication involved identification and elimination of PI animals resulting in getting BVDV-free population (Alenius et al., 1996). After elimination of PI animals, the primary action of the program was control of virus introduction into the herd by direct contact of cattle with PI animal or via newly purchased animal carrying PI foetuses as well as prevention of infection spread by indirect routes such as transportation vehicles, auctions or visitors. The measures pertaining to infected herds encompassed prevention of contacts with cattle and sheep from herds other than those certified as BVDVfree. All animals intended for trade were provided with individual certificate to be free from BVDV infection and to originate from a BVDV-free herd. Owners of BVDV-free herds were advised to purchase new animals exclusively for certified herds. Pregnant seropositive animals were introduced into other herd only if they were seropositive (confirmed presence of antibodies) before conception. The measures taken in infected herds encompassed prevention of contact with animals from other herds, ban on selling animals and purchasing new animals in the period of program duration. Throughout three years, 11,120 (70\%) dairy herds and 3,075 (20\%) beef herds participated in the control program. In this period, 7,585 (47\%) dairy herds and 1,456 (10\%) beef herds were certified as BVDV-free. Vaccination was absolutely excluded (Alenius et al., 1996).

Examination of bulk milk samples within the framework of a program for control of BVDV infection in Denmark encompassed 16,113 dairy herds, and presence of PI animals was established in $39 \%$ of herds. In addition to identification and elimination of viraemic PI animals, the program included the following prophylactic measures: 1) only tested and non-PI confirmed animals could be introduced into the herd;2) any seropositive pregnant heifer that was 
to be introduced into the herd was quarantined until calving and could not enter the herd before the calf was tested PI negative; 3) to prevent occurrence of acute infection in the herd all newly purchase animals were isolated during three weeks; 4) animals were not grazed in areas close to herds suspected to contain PI cattle; 5) common pastures had to be free from PI animals; 6) all animals participating on exhibitions or auctions had to be tested and certified as BVDV-free and non-PI; 7) on the infected farms, the testing encompass also small ruminants; 8) field veterinarians strictly followed relevant biosecurity measures to prevent potential transmission between the herds. The herds were considered free from infection in case of absence of virus specific antibodies in blood serum of three calves older than eight months tested at least 12 months after removal of all PI animals from the herd (Bitsch and Ronsholt, 1995).

In the framework of an experimental program of BVDV infection control in Italy (the Province of Rome), which was based on identification and culling of PI animals blood sera from all animals older than one year from 174 mainly dairy herds were examined (Ferrari et al., 1999). According to the results of serological testing the herds were categorized as negative if none of the animals was tested seropositive. The herd was claimed positive if one or more animals were seropositive. Negative herds underwent repeated testing after 30 days. If the second examination revealed negative result, the herd was declared free from BVDV. To the purpose of maintaining the free status, the tests were repeated every six months including examination of bulk milk sample from the milk tanks from dairy farms or examination of blood samples on beef farms. In seropositive herds, all animals aged 6-12 months were tested for the presence of specific antibodies in serum samples. According to the results, the herds could be categorized as "with or without" recent BVDV infection. In herds without recent infection, seronegative status of 6-12 months old animals was checked at 6-month intervals. If the tested animals (6-12 months of age) have revealed permanent negative results throughout 18 months (three consequent testing at 6-month intervals), the herd could be certified as BVDV-free. In herds characterized by recent infection (one or more seropositive calves aged 6-12 months) all animals were tested for the presence of virus specific antibodies. All seronegative animals were tested for the presence of BVDV virus. The animals were categorized as PI if the virus was detected during two subsequent tests at 30-day interval. Seronegative animals were tested every six months to exclude or confirm new cases of infection. The herd was claimed BVDV-free if all 6-12 months old animals born 12 months after elimination of the last PI cattle were seronegative as well as if there were no seropositive findings in the group of seronegative animals (Ferrari et al., 1999). 
More extensive program for the control and eradication of BVDV in Italy considered the potential application of programmed vaccination. In the herds with high seroprevalence, vaccination of seronegative animals before conception was practiced (Cancelloti and Carlotto, 1985). Adequate information about the status of BVDV infection in the herd was the prerequisite for implementing an adequate vaccination program. Serological and virological examination was performed with an aim of confirming and excluding of PI animals. At the same time, relevant prophylactic measures were applied, including "all in - all out" approach, frequent and thorough disinfection, quarantine and isolation as well as rigorous hygienic measures at calving. The control of BVDV infection in Italy involved attenuated vaccine, which was considered safe and effective prophylactic tool, especially in calves. The heifers on dairy farms were vaccinated at age of 12-14 months. During the period of program implementation, it was established that proper determination/identification of herd status before vaccination was of crucial importance and that vaccination cannot be considered a long-term option. Administration of attenuated and/ or killed vaccine for an indefinite period and without precisely knowing of infectious status of the herd is highly hazardous and economically unacceptable.

During the past few years, the strategies for systematic eradication of BVDV infection were launched in many EU countries. The strategies were initiated either by the governments and relevant authorities or by farmer associations under government's support. The programs are similar to the aforementioned ones, with some minor modifications.

In the Republic of Serbia, the situation is vastly unfavourable - the problem and the control of BVD infection in cattle herds are absolutely neglected. Cattle owners and producers are generally left to their own devices to cope with this problem. During the past several years, there have been some attempts to establish infection control at herd level; however, such isolated attempts received any support from neither governmental authorities nor farm owners, which is partly due to frequent changes of the ownership of the farms during transition period. There were some attempts of applying the Scandinavian system relying on elimination of PI animals and improvement of biosecurity measures on the farm, as well as diverse vaccine preparations. However, neither of efforts proved successful. In that respect, this economical problem that substantially affects the competitiveness of Serbian cattle production was recognized by professionals in veterinary medicine and the management of the Veterinary Directorate of the Ministry of Agriculture and Environmental Protection. They created the initiative for establishing an initially voluntary program for the control of BVD infection in the territory of the Republic of Serbia. 
Researchers from the Scientific Veterinary Institute „Novi Sad“ (NIV-NS) have been permanently participating in the programs for monitoring of infectious animal diseases and zoonoses in Serbia. Thus, Serbian Government placed confidence on the scientific and professional competences of the researchers from NIV-NS and colleagues participating in research project No TR31084 as well as professionals from the sector of animal health protection, and initiated creation of a draft of the Program for the control, suppression and eradication of BVDV infection in Republic of Serbia. The program would be initially implemented on voluntary basis at individual farms and cattle herds, depending on the interest of the owners (Petrović et al., 2015). Considering that the Program for the control of BVDV infection combines successful methodologies developed and applied in several countries (Scandinavian, German, Italian and Slovenian control program), and to the introduced "up to date" diagnostic methods into the laboratories that will be included in animals testing (Petrović et al., 2010), it is expected to be successful in cattle herds that will voluntarily conduct the control of BVDV infection. The Program would be subsequently implemented at national level as a governmental program for the control of BVDV infection in the Republic of Serbia.

\section{METHODOLOGIES PROPOSED FOR CONTROL, SUPPRESSION AND ERADICATION OF BVDV INFECTION}

Primary goal in the control of BVDV is the prevention of prenatal infection. The procedure involves identification and elimination of persistently infected (PI) cattle from the herd (Roeder and Harkness, 1986; Baker, 1987). After elimination of PI animals, particular attention should be paid on introduction of new animals into the herd, avoiding contact infections and preventing the occurrence of transplancental infection (Baker, 1987). The central aspect of this volontary Program for control, suppression and eradication of BVDV infection relies on the establishment of herd free from BVDV infection. Certification of the herds would be coordinated and validated by the Veterinary Directorate that would also be responsible for providing an online database of certified herds with all relevant data pertaining to the herd and certification validity date.

The Program design encompasses several steps, i.e. stages of disease control, depending on the actual status of BVDV infection in a herd.

1. Stage 1: Affirming status "free from BVDV infection“;

2. Stage 2: Obtaining status „, free from BVDV infection;

3. Stage 3: Maintenance of BVDV-free status of the herd and 
4. Stage 4: Loss of the status "free from BVDV infection" and procedure for restoring and reclaiming the status of BVDV-free herd

The goals of this Program Proposal are:

- Reduction of economic losses in cattle herds;

- Obtaining of certified breeding material to facilitate and promote its access to international market;

- Better market price of such breeding material

\section{Stage 1: Affirming the status "free from BVDV infection"}

To affirm the BVDV-free status, the herd needs to fulfil the following conditions:

1. If infection in the herd was not detected throughout past 12 months;

2. If none of the animals manifest clinical signs that would suggest suspect BVDV infection;

3. If the holding (farm, holding yard, pasture, etc.) where the cattle herd is located is protected by either natural or artificial barriers to prevent any undesirable contact between in-farm cattle with animals, people, equipment, tools or vehicles from other farms of poor or unknown/uncontrolled status with respect to BVDV infection (prevent direct and indirect contacts between animals of different health status);

4. If newly purchased animals were introduced into the herd, they should originate from certified BVDV-free herds, or have been isolated quarantined for 30 days and proved negative after relevant testing for the presence of BVD virus and BVDV-specific antibodies (examination performed minimum 15 days after putting into quarantine)

5. If none of the animals from the herd was in contact with cattle originating from herds of unknown BVDV status or herds of poorer BVDV status;

6. If artificial insemination is performed using only semen from the Centres for artificial insemination certified as BVDV-free or from bulls confirmed as free from BVDV infection or if natural breeding is practiced, only the bulls originating from BVDV-free herds or proved BVDV-free bulls are used;

7. If two consequent serological testings for the presence of BVDV-specific antibodies performed at 6-month interval in all animals aged 7-13 months were resulted with negative finding (if there are no animals of such age, the test includes all for six months older animals - animals aged 14-20 months, etc). The period after last previous test must not exceed 6 months. 
Request for certification is submitted to the Veterinary Directorate of the Ministry of Agriculture and Environmental Protection by the owner - farmer. The Request should be previously approved / verified by relevant veterinary inspector according to health status examination (declaration of the relevant veterinary service responsible for herd status monitoring in line with aforementioned terms 1-6) and laboratory analysis pursuant to aforementioned term 7. According to the submitted request and relevant accompanying documentation, Veterinary Directorate of the Ministry of Agriculture and Environmental Protection awards the Certificate on BVDV-free status to the herd with a validity period of 12 months and enters the herd into the database (Register) of herds free from BVDV infection, which would be publicly available from the web-page of the Veterinary Directorate and is automatically updated.

\section{Stage 2: Obtaining of status „free from BVDV infection“"}

If for any reason the herd cannot be declared as BVDV-free according to rules described for the Stage 1 of BVDV control or clinical manifestations or laboratory examination suggest the presence of BVDV infection in the herd, the following steps should be taken towards obtaining of BVD-free status:

1. Examine all animals in the herd for the presence of BVD virus and promptly eliminate (slaughter) all persistently infected animals (PI) from the herd;

2. During one-year period after elimination of all PI animals from the herd, examine every single newborn calf for the presence of BVDV during first week of life and immediately eliminate all virus-positive animals;

3. One year after elimination of the last PI cattle, i.e., BVD-positive animal from the herd, examine all animals aged 7-13 months for the presence of BVDV-specific antibodies and :

a. If testing results are negative, repeat testing after 6 months including all animals aged 7-13 months. If the results of repeated testing for the presence of BVDV-specific antibodies are negative and conditions of the Stage 1 of BVDV control / terms 1-6 are fulfilled, the herd is declared as free from BVDV infection;

b. In case of positive result in repeated testing, the procedure of suppression and eradication of BVDV infection should started from the beginning, that is, from Term 1 of this stage of BVDV control (Stage 2);

3. If there are no animals of such age in the herd at the moment of testing, the test includes all animals from the upper 6-month age category, that is, cattle aged 14-20 months 
The status of a BVDV-free herd is declared if all aforementioned measures and procedures are successfully implemented, resulting in negative finding of two consequent serological testings for the presence of BVDV-specific antibodies performed at 6-month interval in all animals aged 7-13 months (if there are no animals of such age, the test includes all animals from the upper 6-month age category). Request for certification is submitted to the Veterinary Directorate of the Ministry of Agriculture and Environmental Protection by the owner - farmer in line with conditions stipulated under the Stage 1 of BVDV control.

\section{Stage 3: Maintenance of status "free from BVDV infection"}

Maintenance of the BVDV-free herd status relies on implementation of rigorous biosecurity measures and monitoring of herd's health status by relevant veterinary service. The status is verified at 12 -month intervals by serological examination of all animals aged 7-13 months for the presence of BVDV-specific antibodies. Based on the obtained data and negative serological finding the herd certificate is extended for the period of next 12 months. Besides the abovementioned, the herd must comply with all terms stipulated in the Stage 1 of BVDV control, terms 1-6.

If laboratory examination aimed at obtaining disease-free status of uncertified herd or in a certified herd reveals positive serological finding in animals aged 7-13 months, the following steps should be taken:

1. Test all animals in the herd for the presence of BVD virus and promptly eliminate (slaughter) all persistently infected animals (PI) from the herd;

2. During subsequent one-year period, examine every single newborn calf for the presence of BVDV during first week of life (immediately eliminate virus-positive animals);

3. One year after elimination of the last PI cattle, i.e., BVD-positive animal from the herd, examine all animals aged 7-13 months for the presence of BVDV-specific antibodies according to the procedure described under the Stage 1 of BVDV control and if:

a. test results are negative, repeat testing for the presence of BVDVspecific antibodies after 6 months including all animals aged 7-13 months. If the results of repeated testing are still negative and conditions from the Stage 1 of BVDV control / terms 1-6 are fulfilled, the herd is declared free from BVDV infection and the certificate on BVDV-free status is issued; 
b. the result in repeated testing is positive, the procedure of suppression and eradication of BVDV infection is started from the beginning, that is, from Term 1 of this Stage of BVDV control.

3. If there are no animals of such age in the herd at the moment of testing, the test includes all animals from the upper 6-month age category, that is, cattle aged 14-20 months, etc.

The monitoring of herd's health status is performed by relevant veterinary service or institution, which should conduct a detailed and comprehensive inspection at least twice yearly at minimum 4-month intervals. The inspection must include clinical examination of the cattle as well as control of the compliance of farm practices with the terms 1-5 stipulated in the Stage 1 of BVDV control. After the inspection, the relevant institution or veterinary service completes the appropriate Protocol on herd status, that is, whether the conditions for declaring the herd as free from BVDV infection are fulfilled or not. The Protocol is made in three copies submitted to 1) farm owner, 2) veterinary inspector and 3) responsible field veterinarian.

The owner is obligated to report any evident disturbance of health status of his animals that suggests potential BVDV infection as well as each case of abortion to the responsible field veterinarian, who has to perform sampling of materials for virological and serological examination and submit them to relevant laboratory for further testing for the presence of BVDV infection.

The status of a BVDV-free herd is declared if all above stated measures and procedures are completed, and if two consequent serological examinations for the presence of antibodies against BVDV performed at 6-month interval in all animals aged 7-13 months resulted with negative finding (if there are no animals of such age, the test includes all animals from the upper 6-month age category). Request for certification is submitted to the Veterinary Directorate of the Ministry of Agriculture and Environmental Protection by the owner / farmer in line with conditions stipulated under the Stage 1 of BVDV control.

\section{Stage 4: Loss of the status "free from BVDV infection" and procedure for restoring and reclaiming the BVDV-free herd}

If it is established that the requirements for declaring the herd as free from BVDV infection are not fulfilled, the owner is issued a Decision on withdrawal of the certificate on BVDV-free status (or the validity of the certificate is not extended to the further period) by the Veterinary Directorate of the Ministry of Agriculture and Environmental Protection. 
The data on the herd that has lost its status of BVDV-free herd are deleted from the Registry of herds free from BVDV infection by the Veterinary Directorate.

To restore the lost BVDV-free status of the herd, the owner is obligated to fulfil all conditions and procedures for obtaining of the status "free from BVDV“ infection described in the Stage 2 of BVDV control.

Figure 1: Flow diagram for obtaining of BVDV-free status of the herd

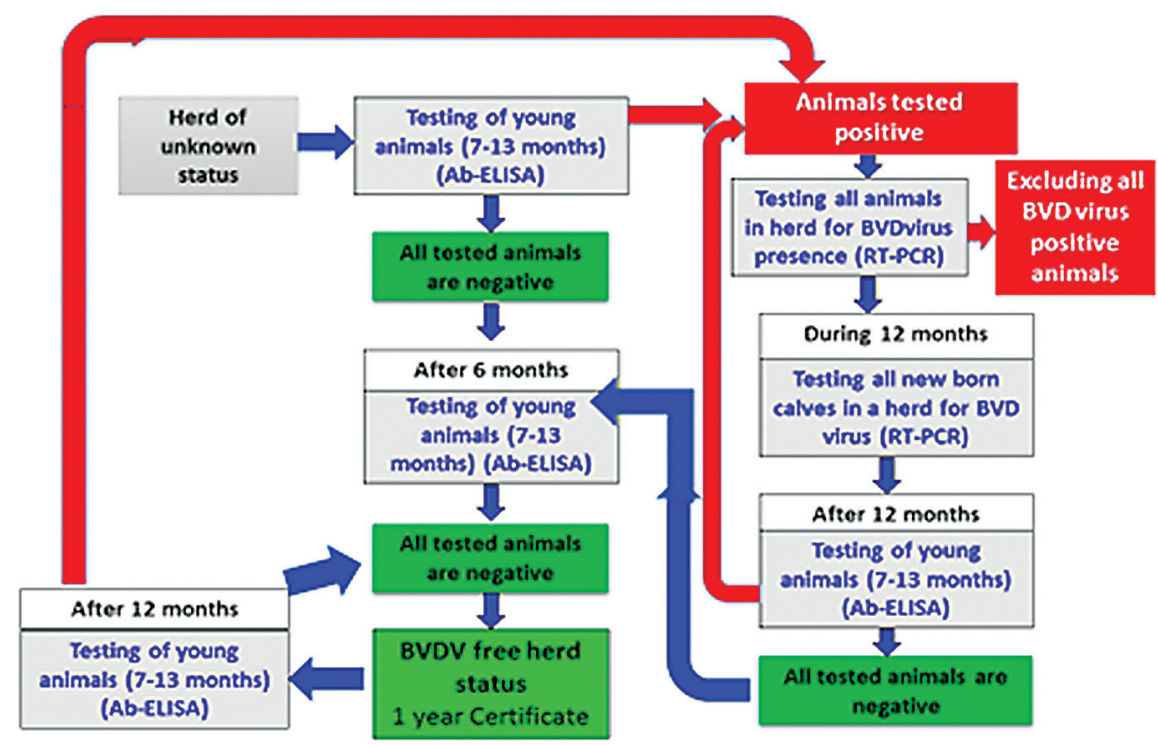

Acknowledgements: This paper is a result of the research within the project TR 31084, funded by the Ministry of Education, Science and Technological Development, Republic of Serbia

\section{REFERENCES:}

1. Alenius S., Lindberg A., Larsson B.: A national approach to the control of bovine viral diarrhoea virus. In: Proc. of the 3-rd ESVV Symposium on Pestivirus Infections, Lelestad, Netherlands, 162-169, 1996

2. Baker J.C.: Bovine viral diarrhea virus: A review; JAVMA, 190, 11, 14491458,1987 
3. Belić L., Mihajlović B., Jermolenko G.: Prilog ispitivanju antitela protiv virusne dijareje goveda. Veterinarski glasnik 8, 565-568, 1973

4. Bitsch V., Ronsholt L.: Control of bovine viral diarrhoea virus infection without vaccines. Vet. Clinics of North America: Food Animal Practice, 11, 3, 627-640, 1995

5. Bronwlie J., Clarke M.C., Howard C.J. : Experimental production of fatal mucosal disease in cattle. Veterinary Record 114, 535-536, 1984

6. Brownlie J.: Pestiviruses of Ruminants; Office International des Epizooties, 59th General Session, 1991

7. Cancellotti F.M., Carlotto F.: Methods and strategies of bovine viral diarrhoea control in Italy. In: Proc. EEC Conference on Pestivirus Infections of Ruminants, Brussels, 183-193, 1985

8. Cvetnić S.: Virusne bolesti životinja, JAZU, Stvarnost, Zagreb, 1983

9. Ferrari G., Scicluna M.T., Bonvicini D., Gobbi C., Della Ferita F., Valentini A., Autorino G.L.: Bovine virus diarrhoea (BVD) control programme in an area in the Rome province (Italy). Veterinary Microbiology 64, 237-245, 1999

10. Houe H.: Epidemiology of bovine virral diarrhea virus. Veterinary Clinics of North America: Food Animal Practice, 11, 3, 521-547, 1995

11. Houe H.: Epidemiological features and economical importance of bovine virus diarrhea virus (BVDV) infections. Veterinary Microbiology 64, 89107, 1999

12. Kurčubić V.: Serološka ispitivanja goveda na infekciju virusom bovine virusne dijareje magistarski rad, Veterinarski fakultet Univerziteta u Beogradu, Katedra za Mikrobiologiju, Beograd,1993

13. Milošević B., Petrović T., Jermolenko Gordana, Stanojević S.: Rasprostranjenost infekcije virusom bovine virusne dijareje kod goveda u beogradskom epizootiološkom području. U: Simpozijum VI epizootiološki dani, Vlasinsko jezero, 31. mart - 2.april 2004. Zbornik kratkih sadržaja, 167, 2004

14. Molnar T, Kiškarolj F, Molnar O.: Bovina virusna dijareja - prva serološka ispitivanja na epizootiološkom području VSI Subotica. U: Zbornik referata i kratkih sadržaja, 5 Jugoslovenski Epizootiološki Dani, Palić, Subotica, 56-59, 2003

15. Nettleton P.F., Entrican G.: Ruminant Pestiviruses. British Veterinary Journal, 151, 6, 615-641, 1995

16. Oirschot J.T., Bruschke C.J.M., van Rijn P.A.: Vaccination of cattle against bovine viral diarrhea. Veterinary Microbiology 64, 169-183, 1999

17. Paton D.J., Sharp G., Ibata G. : Foetal cross-protection experiments between type 1 and type 2 bovine viral diarrhoea virus in pregnant ewes. Veterinary Microbiology 64, 185-196, 1999 
18. Petrović M., Đuričić Bosiljka, Ignjatović R., Stojanović G., Petreski I.: Ispitivanje raširenosti virusne dijareje goveda / bolesti sluzokoža (BVD/ MD) ELISA testom kod mlečnih krava Niškog i Južnomoravskog epizootiološkog područja. U: Zbornik referata i kratkih sadržaja, Sinpozijum IV Jugoslovenski Epizootiološki Dani, Mataruška Banja, 3-6. aprila 2002. 224-226, 2002

19. Petrović T., Lazić S., Savić-Jevđenić S., Lupulović D., Velhner M.: Ispitivanje prisustva specifičnih antitela za BVD virus u krvnim serumima priplodnih goveda na jednoj farmi. U: Zbornik Referata i kratkih sadržaja,Simpozijum III Jugoslovenski epizootiološki dani, Kladovo, 18. - 21. april 2001. godine, 134-143, 2001

20. Petrović T.: Ispitivanje raširenosti infekcije izazvane virusom goveđe dijareje (BVD) kod priplodnih goveda, magistarska teza, Fakultet veterinarske medicine, Univerzitet u Beogradu, Katedra za zarazne bolesti životinja i bolesti pčela, 2002

21. Petrović T., Milošević B., Đuričić Bosiljka, Knežević N.: Prevalence of BVD infection in breeding cattle in southern Backa and Srem district. In: $\ll 5^{\text {th }}$ Pestivirus symposium», 26-29 Avgust, Cambridge, UK, poster No. 18, 2002

22. Petrović T., Lazić S., Lupulović D., Đuričić B.: Bovina virusna dijareja, mesto i značaj u zdravstvenoj problematici u govedarstvu i epizootiološka situacija u našoj zemlji. U: Zbornik referata i kratkih sadržaja, Simpozijum V epizootiološki dani, Subotica 2 - 5.04.2003. godine, 17-25, 2003

23. Petrović T., Lazić S., Lupulović D., Lalić M., Đuričić B.: Štete nastale kao posledica infekcije izazvane virusom virusne dijareje goveda i mogućnosti njene kontrole. Veterinarski glasnik, 57, dodatak 7-8, 449-461, 2003.

24. Petrović, T., Molnar, T., Milošević, B., Kurčubić, V., Petrović, M.M., Bojanić, M., Lazić, S., Đuričić, B.: Some examinations of prevalence of BVD infection in Serbia and Montenegro.. In: Book of Abstracts,Second European Symposium on: BVDV Control, Porto, Portugal, Octobar 20 - 22, 80, 2004.

25. Petrović T., Đuričić B, Toplak I., Lazić S., Barlič Maganja D., Hostnik P., Grom J., Sandvik T.: Isolation and confirmation of bovine viral diarrhoea virus in Serbia and comparative typing with recent Slovenian isolates. Acta Veterinaria, 1-2, 299-312, 2004

26. Petrović T., Lazić S., Polaček V., Đuričić B.: Rezultati ispitivanja raširenosti BVDV infekcije u malim zapatima goveda na području Južnobačkog i Sremskog okruga u toku 2004. godine U: Zbornik radova i kratkih sadržaja, 17. Savetovanje veterinara Srbije, Zlatibor 07 - 10.09.2005, Srpsko veterinarsko društvo, 82-83, 2005. 
27. Petrović T.: Identifikacija i genetska analiza izolovanih sojeva virusa goveđe dijareje (BVD) na području Republike Srbije, doktorska disertacija, Fakultet veterinarske medicine, Univerzitet u Beogradu, 2006.

28. Petrović T., Lazić S., Lupulović D., Bugarski D., Đuričić B.: Rezultati ispitivanja raširenosti BVDV infekcije u velikim i malim zapatima goveda na području Južnobačkog i Sremskog okruga. Arhiv veterinarske medicine, ISSN 1820-9955, 1, 2, 15-34, 2008

29. Petrović T., Velhner M., Petrović J., Stojanov I., Grgić Ž., Lazić S.: Savremene metode laboratorijske dijagnostike u veterinarskoj medicini i mogućnosti njihove primene $=$ Modern laboratory diagnostic methods in veterinary medicine and the possibility of its application. Arhiv veterinarske medicine, ISSN 1820-9955, 3, 1, 39-61, 2010

30. Petrović T., Lazić S., Bugarski D., Lupulović D., Polaček V., Vidanović D., Plavšić B.: Predlog Programa kontrole, suzbijanja i iskorenjivanja infekcije izazvane virusom goveđe virusne dijareje u zapatima goveda u Republici Srbiji. Novi Sad, Naučni institut za veterinarstvo (tehničko rešenje), 2015

31. Roeder P.L., Harkness J.W.: BVD virus infection: Prospects for control. Vet. Rec. 118, 143-147, 1986

32. Waage S., Krogsrud J., Nyberg O.: The Norwegian programme for eradication of bovine viral diarrhoea / mucosal disease. In: Proc. XVIII World Buiatrics Congress, Bologna, Italy, 773-776, 1994

Primljeno: 25.11.2015.

Odobreno: 15.01.2016. 